\title{
Determining Compoundhood in Ígálà: From Universal to Language Specific Focus
}

\author{
Gideon Sunday Omachonu \& \\ Williams Sunday Onogu \\ Humboldt University / Nasarawa State University \& \\ Kogi State University
}

\begin{abstract}
In spite of the fact that compounding is really pervasive in the world's languages and despite the huge volume of literatures on compounding in languages, a critical assessment of the extant literature on compounding reveals that providing satisfactory criteria for defining and or determining compoundhood still requires both language specific and cross-linguistic investigations for dependable linguistic generalizations. As it were, there are hardly any universally
\end{abstract}

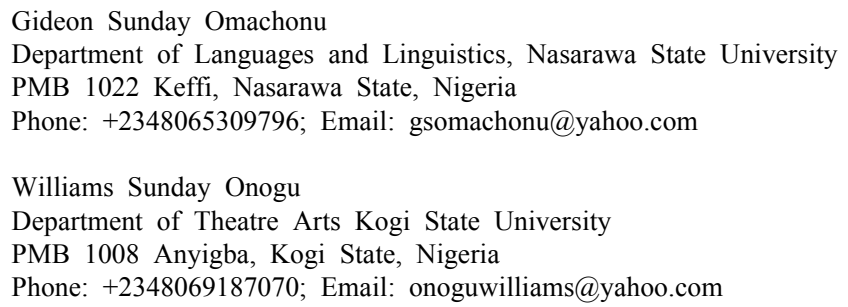

Received June 18, 2012; Revised August 2, 2012; Accepted August 24, 2012. 
accepted criteria for determining compoundhood, hence the focus of reasearch is how to determine compounding across languages. In Ígálà, 1 in particular, not much attention has been devoted to describing compounding. The present study therefore investigates compounding and or compound word formation in Ígálà, a West Benue-Congo language spoken in north central Nigeria. Defining compoundhood and distinguishing compound words in Ígálà, the study shows, favours semantic criteria such as unity of concept, semantic specialization, permanent aspect, and unitary representation of concept above phonological and syntactic considerations. Compounding generally has been found to be a highly productive word formation process in Ígálà in terms of forms and functions. For instance, apart from Noun + Noun nominal compounds, other compound types such as verbal as well as synthetic compounds have been attested in the language. Besides, in addition to the general function of lexical expansion through creation of new lexical categories or lexemes, compounding has been used copiously in naming concepts, particularly foreign institutions, ideas, items, objects and or concepts that were hitherto non-existent in Ígálà.

Keywords: Ígálà, compounding, defining criteria, forms and functions

\section{Introduction}

To the best of these writers' knowledge, not much attention has been devoted to describing compounding in Ígálà. Earlier works such as Armstrong's (1951) and (1965) preliminary reports on the

1 Ígálà belongs to the West Benue-Congo and is more precisely one of the 'Yoruboid' languages in North-Central Nigeria. It is a dominant language in Kogi State; spoken by over two million natives in nine Local Government Areas of the state. The language is equally spoken in some communities outside Kogi state: Èbú in Delta state, Ólóhí and İfèkwù in Edo State, Ógwúrúgwú, Òjó, İgá, and Àsàbá in Enugu State, Òdòkpè, Ńjàm, Ìnómà, Àlá, İgbédò, Ónúgwá, Òdè, İgbòkènyi, and Ìlá in Anambra State (cf. Omachonu 2012). 
language did not focus on the subject matter. What comes closest to it, though not in-depth, is his treatment of vowel elision in some Ígálà compound words. Similarly, even Omachonu (2001) which examines morphological processes in Ígálà is not as detailed on compound word formation. In the same vein, Atadoga (2011) did not go far on this. His added contribution is merely a distinction between compounds and complex words in Ígálà.

In addition, even with those languages in Nigeria, for instance, in which a fair amount of attention has been devoted to the description of compounding-Yorùbá (Bamgbose 1967; Owolabi 1995; Awobuluyi 2005; Oyebade 2007; Taiwo 2008, 2009), İgbò (Anagbogu 1990, 1995, 2000; Nwaozuzu 1991; Oluikpe \& Nwaozuzu 1995; Iloene 2007), Ùrhòbò (Aziza 2007), and Kọ̀ríng (Anagbogu 2003, 2011) - a critical look at the extant literature on compounding in the languages (even African linguistics in general) would reveal that providing satisfactory criteria for defining or determining compoundhood still requires both language specific and cross-linguistic investigations for dependable linguistic generalizations. Thus phonological, syntactic as well as semantic criteria have been proposed and used in the analysis and definition of compoundhood across languages (see Lieber \& Štekauer 2009). Even though compounding is really pervasive in the world's languages to the extent that it could be said to be a universal linguistic phenomenon (Greenberg 1963), defining compoundhood has been somewhat controversial in many languages (see Nwachukwu 1983 and especially Nwaozuzu 1991 for a detailed account of such controversy in İgbò studies on nominal compounds in İgbò). Against this background therefore, the present study takes language specific approach as it seeks to provide answers to the following questions on compounding in Ígálà:

What features characterize compounding or compound word formation in Ígálà and to what extent is compounding a productive linguistic process in the language in terms of 
varieties (forms) and functions?

In what follows therefore, we begin by arguing for universality of compounding before proceeding to give an overview of compounding and compound word formation processes in Ígálà. In addition, we provide a robust discussion on the features or criteria for defining and distinguishing compounds especially nominal compounds from grammatical structures of similar constituents in the language.

\section{Universality of Compounding}

Compounding is a prominent word formation process which is attested when in a language two or more words (lexemes) are put together to form another. This process is very productive in many languages of the world (if not all) including most African languages. Therefore, it could be said to be a universal linguistic phenomenon. Or, are there really any languages without compound words or any productive compounding processes? Greenberg's (1963: 92) answer may still suffice: "There are a considerable number of languages without inflections, perhaps none without compounding and derivation." In fact, most natural languages have compound nouns at least (Plag 2003, Kortmann 2005). Even though lately there has been an emerging concern that research in typology and linguistic universals has dedicated little attention to compounding with a commonplace assumption that compounding is really pervasive in the world's languages (Guevara \& Scalise 2009), the phenomenon has been investigated and adequately described in many languages of the world (see Lieber \& Stekauer 2009). However, a critical assessment of the extant literature on compounding in linguistics reveals that providing satisfactory criteria for defining and or determining compoundhood still 
requires both language specific and cross-linguistic investigations for dependable generalizations. Lieber \& Štekauer (2009: 2-3), for instance, identify two main reasons why it is difficult to come up with satisfying and universally applicable definition or features for determining compoundhood:

On the one hand, the elements that make up compounds in some languages are not free-standing words, but rather stems or roots. On the other, we cannot always make a clean distinction between compound words on the one hand and derived words or phrases on the other.

Therefore, in spite of the extensive research into compounds and compounding processes, there are hardly any universally accepted criteria for determining what a compound is. As it were, even though compounding is adjudged to be a universal linguistic phenomenon (Greenberg 1963), since there are hardly any universally accepted criteria for determining compoundhood in languages, the focus of reasearch is and has been how to determine compounding across languages.

\section{Defining Compoundhood in Ígálà: An Overview}

The two major means of creating new words especially lexical categories such as nouns, verbs, and adjectives in language are compounding and derivation. Compounding, as defined earlier, is a prominent word formation process which is attested when in a language two or more words are put together to form another (new word). Compounding or composition which is the most frequently used means of producing new lexemes has its overall defining property as "consisting of the combination of lexemes into larger words" (Booij 2007: 75). Even though this may not be a 
universally applicable distinction, the crucial demarcation between compounds and derived words in most languages is that compounds consist of free-standing lexemes whereas derived words, in most cases, contain affixes in the form of non-lexemic morphemes (see Lieber \& Štekauer 2009). The distinction is not always so clear-cut because (i) "a lexeme may develop into a derivational morpheme" (cf. Booij 2007: 85), and (ii) the elements that make up compounds in some languages may not be free-standing words, but rather stems or roots (see also Lieber \& Štekauer 2009). However, the use of the term lexeme, Lieber \& Štekauer argue, is "specific enough to exclude affixes but broad enough to encompass the roots, stems, and free words that make up compounds in typologically diverse languages" (p. 2). In Ígálà, while we take examples (1a-c) below as typical (nominal) compounds, the examples in (2a-c) are considered as derived words with obvious presence of affixes (bound morphemes, prefixes) in the derivations. ${ }^{2}$

(1) a. ọ̀là \# word

ọ́dà command ọ̀là ọ́dà 'law'

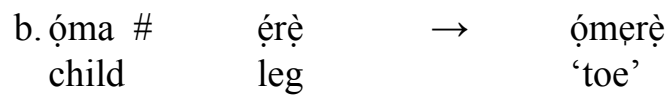

\begin{tabular}{|c|c|c|}
\hline $\begin{array}{l}\text { c. ùrà \# } \\
\text { enjoyment }\end{array}$ & $\begin{array}{l}\text { èdọ̀ } \\
\text { heart }\end{array}$ & $\rightarrow$ \\
\hline
\end{tabular}

(2)
a. ù +
kọ́chẹ
$\rightarrow$
ùkóchẹ
affix
learn
'lesson'
b. á +
kóchẹ
$\rightarrow$
ákọchẹ
affix
learn
'learner'

2 For all Ígálà data used in this paper, tone is marked as follows: v́ for High, $\grave{v}$ for Low but Mid tone is left unmarked. 


$\begin{array}{lll}\text { c. é }+ & \text { kóchẹ } \\ \text { affix } & \text { learn }\end{array} \quad \rightarrow \quad \begin{aligned} & \text { ékóchẹ } \\ & \text { 'learning' }\end{aligned}$

Nominalisation or deverbal noun formation through the use of prefixes attached to verbs (affixation) as in (2a-c) above is a very productive derivational process in Ígálà. On the contrary, one hardly finds instances of suffixation attested in the derivational morphology of Ígálà. Besides, it appears the nominalising affixes in (2a-c) (prefixes ù, á, é) have their own inherent tones as they neither go on tone copying nor polarization but the tones are either high or low as nouns in Ígálà do not begin on mid tone. However, as it relates to the compounds, the pertinent question to ask is what features define or characterize compounds as distinct from other words and grammatical structures with similar constituents in Ígálà?

In spite of the fact that compounding is common in languages (universal) and despite the overwhelmingly huge volumes of literatures available on compounds and compounding processes in languages, it is still quite appropriate to observe that there are hardly any universally accepted criteria for determining what a compound is in terms of definition, headedness and demarcation between compounds and similar grammatical structures (Lieber \& Štekauer 2009). Hence, as mentioned earlier, phonological, syntactic as well as semantic criteria have been proposed and used in the literature to identify and distinguish especially nominal compounds from grammatical structures (noun phrases \& genitive constructions of similar constituents) in languages (see Nwaozuzu 1991, Anagbogu \& Omachonu (To Appear), and so on).

Fabb (2001) asserts that compounds are subject to phonological as well as morphological processes which may be language specific or specific to compounds. Thus, assimilation, vowel elision, and suprasegmental features like stress, tone, and intonation may play very significant roles in identifying and distinguishing compounds from noun phrases in some languages. For instance, left-hand 
primary stress assignment for nominal compounds in English has proved to be somewhat a useful guide in determining compounding in the language (see Jones 1995, Oslen 2000, Giegerich 2006, Lieber \& Štekauer 2009). Similarly, Finney (2002) has argued for a productive process of compounding in Krio that sometimes involves the application of tonal processes of High deletion and Low spreading. However plausible the proposal for phonological criteria may be in other languages, assimilation or vowel elision and tonal behavior as the data in (1a-c) above exhibit may not sufficiently define and distinguish compounds in Ígálà for a dependable generalization. This is because most of the nominal compounds in the language bear the same or similar tonal patterns as their grammatical counterparts of similar constituents. At best, assimilation, cliticization or vowel elision occasioned by spelling or orthographic representation as in (1b-c) above can only account for Noun + Noun compounds written together as single words. Even at that, these cannot be considered as serious criteria for compound formation in Ígálà because they are not consistently systematic in the language. For example, they can neither account for, nor distinguish Noun + Noun compounds such as in (3a-d) from their noun phrase counterparts.

(3) a. únyí ógwù 'hospital' (compound)
house medicine

b. únyí ógwù 'house of medicine' (NP)

house medicine

c. ómu óyìbó 'sugar' (compound)

salt English/European/name

d. ómu óyìbó 'salt of óyìbó / óyìbó's salt' (NP)

salt English/European/name 
The point is that orthography or spelling convention can hardly be taken as a serious criterion for compoundhood in some languages including Ígálà. For example, in Yorùbá, Bamgbose (1965: 27-28) proposed the use of hyphens for writing Noun + Noun constructions (nominal compounds) meant to be one word, e.g., olóri-burúkú 'a luckless person.' Similarly, in İgbò, whereas Ogbalu (1975) proposed the use of hyphens for writing nominal compounds, Nwachukwu (1983) recommended writing such Noun + Noun constructions as separate lexical items. This means that the writing of (nominal) compounds in these and many other languages is only a matter of individual preferences among the respective scholars. The exception in Czech and Slovak ${ }^{3}$ where spelling has sometimes been considered an important criterion for compoundhood notwithstanding, the written form of compounds could be notoriously inconsistent in some languages (see Szymanek 1988 for such inconsistencies in English compounds: separated with a gap e.g., word list, written together e.g., wordlist, hyphenated e.g., word-list). In all, whether the results of the composition or coming together of the words, Noun + Noun as in (1) and (3a\&c) above are written together as single words, hyphenated or separated with a gap, each represents a new conceptual unit and new lexeme created from the existing lexemes in the language, and therefore must be properly defined and accounted for as such.

Still in search of satisfactory criteria for defining compoundhood and distinguishing compounds from similar grammatical structures, Donalies (2004: 76) proposed ten criteria based on his analyses of Germanic, Romance, Slavic, Finno-Ugric, and Modern Greek constructions. Of the ten criteria given by Donalies, only three could possibly be considered most important for distinguishing compounds across languages (see Lieber \& Stekauer 2009). These are (i) stress and other phonological means, (ii) syntactic

3 In Czech and Slovak, all compounds are spelled as one word whereas syntactic phrases are spelled as separate words in contrast. 
impenetrability, inseparability, and unalterability, and (iii) the behavior of the complex item with respect to inflection. As it has been argued above, phonological criteria have already been dismissed as having very limited relevance for determining compoundhood in Ígálà. This thus leaves us with only the syntactic and semantic criteria as we proceed to examine.

By syntactic impenetrability or inseparability, it means that a complex form is a compound (as opposed to a phrase) if no other element can be inserted between the two constituents (cf. Lieber \& Štekauer 2009). In addition, unalterability which is the other syntactic criterion for compoundhood proposed in the literature relates to the modification of the non-head in a nominal compound. In English, for example, the first stem of a compound (non-head) does not admit modification, whereas in a syntactic construction, modification of the non-head is possible. For instance, while it is possible in English to have a 'very black bird' for a noun phrase, it is definitely not so with 'blackbird' as a nominal compound. In all, the question to ask about these syntactic criteria is the extent to which they can define and distinguish nominal compounds from noun phrases in Ígálà. If one applies the syntactic criteria to the examples (1a-c) and (3a-d) above, one would realize they produce little or no effect in distinguishing the nominal compounds from their grammatical counterparts of similar constituents. For example, in Ígálà, both ọmerẹ̀ 'toe' (compound) and ọma ẹrẹ 'child of leg' (grammatical structure) behave alike in that they do not allow an insertion of any other element between the two constituents, and modification can only apply to the entire construction in each case, e.g., ọmerè lile 'big toe' and ọma ẹrẹ lile 'big child of leg / leg's big child.' The same applies to únyì ógwù kẹkẹ 'small hospital' (compound) and únyì ógwù kẹké 'small house of medicine or small medicine shop/store.' One can therefore conclude that even the use of syntactic criteria cannot help in the definition and demarcation since most nominal compounds resemble grammatical structures of 
similar constituents in the language and they behave alike in relation to certain syntactic operations.

Furthermore, if we consider the morpho-syntactic criterion that deals with the behaviour of the complex item (compound) with respect to inflection, the result would be that even though the lack of inflectional morphemes in Ígálà renders the surface forms of nominal compounds in the language identical to the free grammatical structures in terms of their morphological forms, noun plural formation as it applies to endocentric nominal compounds in the language could provide some useful insights in determining head position in nominal compounds. If, for example, one applies the rule of noun plural formation to nominal compounds in Ígálà, it is the head noun (N1) that undergoes the appropriate plural formation rule. However, this may not give a useful guide for demarcating nominal compounds from noun phrases as both categories maintain identical head position in the language (see Anagbogu \& Omachonu (To Appear), Omachonu (To Appear)).

Thus far, the picture that emerges from the foregoing is that none of the possible criteria discussed so far gives a reliable distinction between nominal compounds and grammatical structures of similar constituents in the language. We may therefore appeal to semantic criteria. Jesperson (1954), Sheard (1966), Levi (1978), Nwaozuzu (1991), Jones (1995), and Olsen (2000) have proposed semantic criteria for defining compoundhood. Of the semantic criteria proposed in the literature, the summary as captured in Nwaozuzu's (1991) semantic criteria for nominal compounds in İgbò may appear more relevant for the present study. For Nwaozuzu, while holding the first two criteria constant, any complement-head structure $(\mathrm{N}+\mathrm{N})$ combination that satisfies any three of these four criteria could qualify as nominal compound in İgbò: (i) unity of concept, (ii) semantic specialization, (iii) permanent aspect, and (iv) unitary representation of concept. By unity or oneness of concept, it means a compound denotes single new idea rather than a combination of ideas suggested by the 
original words (the constituents) thereby naming a new semantic whole. And by semantic specialization, it means the compound refers to a combination of words which has acquired a special meaning in a language to the extent of being adjudged as, at least, having become partly lexicalized and semantically specialized that its specific referent is no longer readily predictable from the surface constituents (see Jesperson 1954, Sheard 1966, Levi 1978). Similarly, by permanent aspect, it means the bond between elements that form a compound must be intimate, irreversible, and permanent and not just a casual association. As Levi (1978) has argued, the compound 'water bug' could only name insects that have some permanent association with water such as living in it or around it and not just a mere casual association or accidental connection of falling into the water. In the same vein, ómerè 'toe' in Ígálà is a permanent part of the leg and únyì ógwù is a house permanently designated for health delivery/services, likewise únyi ùkóche 'school' can only refer to a building or premises where teaching and learning take place on regular or permanent basis. These and many other compounds in Ígálà are given rise to by such permanent association between elements that form the compounds in the language.

Lastly, the term 'unitary representation of concept' means, unlike in the noun phrase where the head-word alone can take the place of the entire phrase, none of the elements constituting a nominal compound can semantically and wholly stand in for the compound single handedly in the grammar of the language. As Omachonu (To Appear) argues, in Ígálà, ọma 'child,' for instance, can stand in for the noun phrase óma óko 'Oko's child or child of farm (if oko is taken to mean 'farm' instead of a personal name)' as its head-word which bears the phrase's most general meaning. The same goes for ilo 'hair' and iye 'mother' for the noun phrases ilo àgbà 'hair of chin' and ìye óko 'mother of husband or husband's mother' respectively. But this is not possible with their compound counterparts as each of the elements that 
constitute a compound cannot represent the full meaning of the compound. For example, ọma 'child' in Ígálà even as the head of the nominal compound ómoko cannot single handedly translate into 'debased fellow' ómoko. Similarly, ilo 'hair' and iye 'mother' even as heads of the nominal compounds ilagbà and iyoko cannot single handedly translate into 'beard' ilagbà, and 'mother-in-law' iyoko respectively in the grammar of Ígálà.

\section{Other Types of Compounds in Ígálà}

Apart from the Noun + Noun compounds as exemplified in (1a-c) and (3a-d) as well as those used for illustrations in the preceding paragraph, other compound types which can equally be accounted for using the semantic criteria enunciated above are Noun + Verb $^{4}$ collocations, Noun + Adjective, Verb + Verb as well as Verb + Noun collocations as examples (4), (5), (6), and (7) below show.

(4) NOUN + VERB
a. éfù \#
biệne

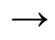
éfù biẹ́ne stomach
be.bad
'ill-manner'
b. ówó \#
nẹ
$\rightarrow$
ówó nẹ
hand
have
'ownership'
c. èdọ̀ \#
lichì
$\rightarrow$
èdòlichì
heart
fossilize
'long-suffering'

4 In Ígálà, most verbs are monosyllabic in structure and many of the disyllabic or polysyllabic verbs are derived through incorporation and amalgamation. Besides, verbs and adjectives are consonant initial while nouns are vowel initial in the language (see also Omachonu 2012). 
(5) NOUN + ADJECTIVE
a. èdò̀ \#
dúdú
$\rightarrow$
èdọdúdú
heart
black
'sorrow'
b. óla \#
fẹ
$\rightarrow \quad$ óla fẹ́
body
clean
'luck'
c. èdò̀ \#
kpábié
èdọ̀kpábié
heart
defile
'annoyance'
$\rightarrow$

(6) VERB + VERB
a. rá \#
run
nó
$\rightarrow$
ránó
'pursue'
b. gwú \# pull
chase

$\begin{array}{ll}\text { pull } & \text { become weak } \\ \text { c. dá } \# & \text { tẹ́ } \quad \rightarrow \quad \text { dissolve (a } \\ \text { cut } & \text { put set apart/aside 'consecrate' }\end{array}$

(7) VERB + NOUN
a. rá \#
úlé
a run/race
rúlé
run
'to run'
b. ro \#
ákwú
$\rightarrow$
rákwú
cry
a cry
'to cry'
c. ne \#
éjú
$\rightarrow \quad$ néjú
have
eye
'to expect'

From their meanings or glosses, we could see that the words in (4), (5), (6), and (7) exhibit most of the semantic characteristics or features of compoundhood enunciated earlier above namely; unity or oneness of concept, semantic specialization, permanent 
aspect, and unitary representation of concept. Furthermore, in (4) and (5), even though the syllable structures of the verbs and the adjectives look very much alike, the semantic realization of the words in the contexts under review would determine the meaning and class of word ascribed to each of the words. For instance, the words fé and kpábié could be used as either verbs or adjectives depending on the context and or the collocation. Besides, the words in (4) and (5) above in addition to being recognized as nominal compounds in the Ígálà lexicon behave somewhat like idiomatic expressions (constructional idioms) in that their meanings are not solely determined by the composition or the sum total of the meanings of the constituents (lexemes) that make up the compounds. This confirms Kavka's (2009) view that compounds can be viewed and also studied as idiomatic expressions because "they show quite a few features and properties that are characteristic of idiomatic expressions . . . they share with idiomatic expressions the ways in which they arise, their existence proper, and their interpretation" (p. 43).

In (6), most of the Verb + Verb collocations for verbal compounds were originally serial verbs that got lexicalized over time as compound verbs (cf. Omachonu 2012) to express somewhat new conceptual units as they function as new lexemes in the language. In the same vein, the Verb + Noun collocations in (7) are instances of noun incorporation where the noun originally functions as an argument of the verb. Even though Bybee (1985) posits that incorporation may differ from compounding in certain ways including phonological or morphological differences; e.g., segment loss (found in Tiwi incorporation words), and that the incorporation of a word may depend on its semantic class, e.g., "in Pawnee it is mainly body part words which are incorporated" (cf. Fabb 2001: 3), we find it more plausible to interpret noun incorporation as a compounding process in Ígálà. Whereas loss of segment (vowel elision), for instance, is almost a regular feature of Noun + Noun compounds that are written as single words in 
Ígálà, incorporation compounds as found in Verb + Noun collocation in the language is not so restricted semantically. Hence, one finds it more plausible to classify noun incorporation in Ígálà as a kind of compounding (see example (7a-c) above).

Yet, another type of compound that has been discovered to be very productive in Ígálà is synthetic compound or what some earlier writers on compounding in Ígálà have christened 'compound complex' word formation (Atadoga 2011, to be more precise). A synthetic compound, in the opinion of Fabb (2001), is a compound whose head is derived from a verb by affixation, and where the non-head fulfills the function of argument or complement of the verb. Observe $(8 \mathrm{a}-\mathrm{c})$ below as they exist in Ígálà.

(8) AFFIX + VERB + NOUN

\begin{tabular}{|c|c|c|c|c|}
\hline $\begin{array}{r}\text { a. á }+ \\
\text { AGT }\end{array}$ & $\begin{array}{l}\text { je \# } \\
\text { eat }\end{array}$ & $\begin{array}{l}\text { óde } \\
\text { hunting }\end{array}$ & $\rightarrow$ & $\begin{array}{l}\text { ájode } \\
\text { 'hunter' }\end{array}$ \\
\hline $\begin{array}{l}\text { b. á }+ \\
\text { AGT }\end{array}$ & $\begin{array}{l}\text { nyá \# } \\
\text { bargain }\end{array}$ & $\begin{array}{l}\text { ájá } \\
\text { market }\end{array}$ & $\rightarrow$ & $\begin{array}{l}\text { ányájá } \\
\text { 'trader' }\end{array}$ \\
\hline $\begin{array}{l}\text { c. è }+ \\
\text { AGT }\end{array}$ & $\begin{array}{l}\text { ló \# } \\
\text { cultivate }\end{array}$ & $\begin{array}{l}\text { úché } \\
\text { farm }\end{array}$ & $\rightarrow$ & $\begin{array}{l}\text { èlúché } \\
\text { 'farmer' }\end{array}$ \\
\hline
\end{tabular}

(9) AFFIX + VERB + NOUN
a. ù +
wó \#
èdò
$\rightarrow \quad$ ùwédò
affix
be.angry
heart
'anger'
$\begin{array}{cc}\text { b. è }+ & \text { yó \# } \\ \text { affix } & \text { be.fat }\end{array}$
óyó
fat
$\rightarrow \quad$ èyóyó
'fatness'
$\begin{array}{ll}\text { c. ù }+ & \text { gbó \# } \\ \text { affix } & \text { be.strong }\end{array}$
èdò
$\rightarrow \quad$ ùgbẹ́dò
heart
'courage' 


\begin{tabular}{|c|c|c|c|c|}
\hline $\begin{array}{l}\text { NOUN + } \\
\text { a. èdò̀ \# } \\
\text { heart }\end{array}$ & $\begin{array}{l}\text { AFFIX } \\
\text { é }+ \\
\text {-ing }\end{array}$ & $\begin{array}{l}\text { ERB } \\
\text { je } \\
\text { eat }\end{array}$ & $\rightarrow$ & $\begin{array}{l}\text { èdòéje } \\
\text { 'patience' }\end{array}$ \\
\hline $\begin{array}{c}\text { b. éjú \# } \\
\text { eye }\end{array}$ & $\begin{array}{l}\text { é + } \\
\text {-ing }\end{array}$ & $\begin{array}{l}\text { fó́ } \\
\text { knead }\end{array}$ & $\rightarrow$ & $\begin{array}{l}\text { éjú éfó } \\
\text { 'blindness' }\end{array}$ \\
\hline $\begin{array}{l}\text { c. èpí \# } \\
\text { penis }\end{array}$ & $\begin{array}{l}\text { é }+ \\
\text {-ing }\end{array}$ & $\begin{array}{l}\text { dá } \\
\text { cut }\end{array}$ & $\rightarrow$ & $\begin{array}{l}\text { èpíédá } \\
\text { 'circumcision' }\end{array}$ \\
\hline $\begin{array}{l}\text { d. èdò \# } \\
\text { heart }\end{array}$ & $\begin{array}{l}\text { è }+ \\
\text { affix }\end{array}$ & $\begin{array}{l}\text { gbo } \\
\text { be.stron }\end{array}$ & 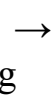 & $\begin{array}{l}\text { èdègbó } \\
\text { 'personal name }\end{array}$ \\
\hline
\end{tabular}

What is synthetic in a synthetic compound in Ígálà is that it usually results from double operation which seems to take place almost simultaneously; derivation and compounding. Whereas in (8), we have agent or action nouns, in (9), we have abstract nouns. Even though it could be argued that in Ígálà, as it relates to the data in (8)-(9), an operation of compound formation in which the verb/noun relation that naturally looks like an argument structure (noun incorporation) occurs before the deverbal noun formation, e.g., nyájá 'to trade' before ányájá 'trader' (8b) and wédò 'to be angry' before ùwédò 'anger' (9a), a more intuitive and plausible explanation would be to say that derivation occurs first to achieve deverbal noun formation before compounding with the deverbal noun as head. The former will be a mere process of nominalization through derivation. Besides, against the English or other Germanic languages' derivational format of $[[\mathrm{N}][\mathrm{V}-\mathrm{Suffix}] \mathrm{n}] \mathrm{n}$ (where $\mathrm{N}$ is interpreted as an argument of $\mathrm{V}$ ) for synthetic compounds (Booij 2007), in Ígálà, the appropriate format for (8)-(9) would be to reverse the existing schema thus: $[[$ Prefix-V] $[\mathrm{N}] \mathrm{n}] \mathrm{n}$. This is largely because of the point made earlier that Ígálà language lends itself more to prefixation whereas suffixation is hardly attested. The sequence (derivation followed by compounding) attested for 
synthetic compounds in Ígálà agrees with Gaeta's (2010) position that a way to deal with the two-faced nature of synthetic compounds is via derivation followed by compounding.

The difference between (10) and (8)\&(9), however, is that in (10), the primary nouns (mainly body parts affected in the process) precede the derived nouns (gerund) instead. There are two possible ways to interpret or analyse the head position in the synthetic compounds in (10) above. The first is to assume that they are exocentric and therefore do not necessarily require a head. The second is to argue that it is possible for synthetic compounds in Ígálà to have either Right-Hand or Left-Hand head position. Unlike the derived nouns recognized as occupying head position in $(8) \&(9)$, the primary nouns in (10), even though they refer to the parts in the body where the actions or the concepts apply, cannot serve as heads in the constructions. This is because judged by semantic interpretation; the head of a compound is a hyperonym of the compound, that is, when A denotes a set $\mathrm{X}$, the head of A denotes a superset of $\mathrm{X}$. This way, in line with the schema which holds that a $\mathrm{N} 1+\mathrm{N} 2$ compound in Ígálà denotes a (special) kind of N1 which is the head noun (cf. Omachonu (To Appear)), èdòéje 'patience' and èdègbó (though also used as personal name) $(10 \mathrm{a} \& d)$ are some kinds of states or attributes of the heart and not kinds of heart. Similarly, éjú éfó 'blindness' (10b) is a state of the eye, not a kind of eye and èpiédá 'circumcision' (10c) is clearly not a kind of penis but the act (an act) of removing the foreskin. By this consideration, the derived nouns in the compounds: éje, ègbó, éfó, and édá which refer to attributes, states and or an act respectively qualify as heads in the construction except that instead of occupying N1 position as in other endocentric synthetic and nominal compounds in Ígálà, they occupy N2 position. And this forms the basis of the argument that synthetic compounds in Ígálà could exhibit either Right-Hand head position or Left-Hand head position. However, the Right-Hand head rule found in (10a-d) may not be very productive in the 
language. It is rather an exception than the rule. This may require further investigation. After all, no study is an end in itself.

In addition, it is possible to derive, even more complex synthetic compounds in Ígálà which one may assume, do not necessarily identify with particular words as 'heads' but which contrary to the assumption go in tandem with other endocentric nominal compounds in Ígálà which have as head the first member (N1) of the constructions. In the case of the synthetic compound however the head is a derived noun (deverbal noun). Consider examples (11a-c) below with the same or similar derivation pattern as (8) and (9) above.

\begin{tabular}{|c|c|c|c|c|c|c|}
\hline $\begin{array}{l}\text { (11) a. ù- } \\
\text { affix }\end{array}$ & $\begin{array}{l}\text { gbà- } \\
\text { receive }\end{array}$ & $\begin{array}{l}\text { álu- } \\
\text { mouth }\end{array}$ & $\begin{array}{l}\text { té- } \\
\text { put }\end{array}$ & $\begin{array}{l}\text { ánè } \\
\text { down }\end{array}$ & $\rightarrow$ & $\begin{array}{l}\text { ùgbálútánè } \\
\text { 'promise' }\end{array}$ \\
\hline $\begin{array}{l}\text { b. ̀̀- } \\
\text { affix }\end{array}$ & $\begin{array}{l}\text { gbó- } \\
\text { tear }\end{array}$ & $\begin{array}{l}\text { á- } \\
\text { affix }\end{array}$ & $\begin{array}{l}\text { ne- } \\
\text { have }\end{array}$ & $\begin{array}{l}\text { úkpò } \\
\text { cloth }\end{array}$ & $\rightarrow$ & $\begin{array}{l}\text { ègbánukpò } \\
\text { 'rag' }\end{array}$ \\
\hline $\begin{array}{l}\text { c. ù- } \\
\text { affix }\end{array}$ & $\begin{array}{l}\text { mà- } \\
\text { know }\end{array}$ & $\begin{array}{l}\text { éjú- } \\
\text { eye }\end{array}$ & $\begin{array}{l}\text { é- } \\
\text { affix }\end{array}$ & $\begin{array}{l}\text { che } \\
\text { do }\end{array}$ & $\rightarrow$ & $\begin{array}{l}\text { ùméjúéche } \\
\text { 'skill' }\end{array}$ \\
\hline
\end{tabular}

Whereas $(11 \mathrm{a} \& \mathrm{c})$ translate as an act and a kind of knowledge respectively, (11b) designates a state of the cloth as being torn or faded to the extent of being considered as rag by ánukpò 'one who is wealth and has many clothes.'

It is important to note that synthetic compounds play a crucial role in the development of linguistic theory, since they raise a number of questions concerning the morphology-syntax interface. For instance, it has been argued that two different options are available in accounting for the argumental relation between head and modifier in synthetic compounds. It is either that lexical derivation is coupled with a syntax-driven operation which is responsible for argument inheritance or that argument inheritance simply results from semantics (cf. Hebblethwaite 2002). The 
former is mostly the case for Ígálà synthetic compounds with a 'head.'

Lastly, compounding has generally been recognized as an important means of extending the lexicon of a language through the creation of new lexical categories such as nouns and verbs mainly (in Ígálà, for example). As Altmann (1988: 100) has argued, "The basic motivation for forming compounds is naturally the need to express a concept not having as yet a sound form," which a speaker can use to express himself. It becomes obvious therefore that so many concepts in so many languages "may only find expression in compounds as there are needs to express these new concepts with new words" (Oluikpe \& Nwaozuzu 1995: 230). Therefore, in addition to the variety of compounds discussed so far, there are two major areas in which the function of lexical expansion or extension through compounding is found very robust and highly productive in Ígálà. It is in the representation of foreign concepts, ideas and institutions that were hitherto non-existent in the Ígálà Kingdom and culture, and the use of reduplicative nominal compounding for creating new lexemes especially kinship terms in the language. In Ígálà, compounding has been used copiously in naming concepts, particularly foreign institutions, ideas, items/objects, and concepts which have been adopted within the host culture and system. The following examples, (12a-c) will suffice.

$\begin{array}{clc}\text { (12)a. únyí } & \text { ùkóchẹ } & \text { 'school' } \\ \text { house } & \text { lesson } & \\ \begin{array}{c}\text { b. únyí } \\ \text { house }\end{array} & \begin{array}{l}\text { ógwù } \\ \text { medicine }\end{array} & \text { 'hospital' } \\ \begin{array}{c}\text { c. únyí } \\ \text { house }\end{array} & \begin{array}{l}\text { dúdú } \\ \text { black }\end{array} & \text { 'prison' }\end{array}$




$\begin{array}{cll}\begin{array}{c}\text { d. únyí } \\ \text { house }\end{array} & \begin{array}{l}\text { àjo } \\ \text { judgment }\end{array} & \text { 'court' } \\ \begin{array}{c}\text { (13) a. òlàfíà } \\ \text { fine }\end{array} & \begin{array}{l}\text { àngòla } \\ \text { skin }\end{array} & \text { 'health' } \\ \begin{array}{c}\text { b. ànyà } \\ \text { horse }\end{array} & \begin{array}{l}\text { ébíjè } \\ \text { iron }\end{array} & \text { 'bicycle' } \\ \begin{array}{c}\text { c. ókò } \\ \text { canoe }\end{array} & \begin{array}{l}\text { ójálè } \\ \text { sky }\end{array} & \text { 'aeroplane' } \\ \begin{array}{c}\text { d. ókò } \\ \text { canoe }\end{array} & \begin{array}{l}\text { ánè (ókanè) } \\ \text { land }\end{array} & \text { 'train' } \\ \text { (14) a. ákòlà } & \text { ójó } & \\ \text { AGT.say.word } & \text { God } & \text { 'preacher' } \\ \text { b. áté } & \text { álè (átálè) } & \text { 'evangelist' } \\ \text { AGT.put } & \text { AGT.go } & \\ \text { c. ákó } & \text { ùkó (ákúko) } & \text { 'teacher' } \\ \text { AGT.teach } & \text { instruction } & \\ \text { d. á.kà } & \text { àjo (ákàjo) } & \text { 'judge' } \\ \text { AGT.say } & \text { judgment } & \\ & & \end{array}$

In addition, reduplicative nominal compounds have been used to derive kinship or family tree terms in the language as shown in (15).

(15)a. óma \#
child $\quad \begin{aligned} & \text { óma } \\ & \text { child }\end{aligned} \quad \rightarrow \quad \begin{aligned} & \text { óma óma } \\ & \text { 'grandchild' }\end{aligned}$


112 Determining Compoundhood in Ígálà

$\begin{array}{clll}\begin{array}{c}\text { b. íye \# } \\ \text { mother }\end{array} & \begin{array}{l}\text { íye } \\ \text { mother }\end{array} & \rightarrow & \begin{array}{l}\text { íye íye } \\ \text { 'grandmother' }\end{array} \\ \begin{array}{cll}\text { c. àtá } \# \\ \text { father }\end{array} & \begin{array}{l}\text { àtá } \\ \text { father }\end{array} & \rightarrow & \begin{array}{l}\text { àtá àtá } \\ \text { 'grandfather' }\end{array} \\ \begin{array}{c}\text { d. òókwó \# } \\ \text { grandparent }\end{array} & \begin{array}{l}\text { òókwó } \\ \text { grandparent }\end{array} & \rightarrow & \begin{array}{l}\text { òyíkwó òyíkwó } \\ \text { 'great grandparent' }\end{array}\end{array}$

From the foregoing, it may be plausible to argue that with regard to lexical expansion or creating new lexical categories or words particularly for foreign institutions, ideas, items or objects, and concepts which were hitherto non-existence in a host language, the use of compounding or equivalent compound word formation to express them as the Ígálà data above (12)-(14) have shown, may be more productive, more natural, and much more motivating than mere borrowing and or transliteration. And by implication, since compounding is a universal phenomenon which is really pervasive in the world's languages, this observation may be applicable to almost all other languages of the world as it relates to lexical expansion through compounding.

\section{Conclusions}

In spite of the fact that compounding is adjudged to be a universal linguistic phenomenon (Greenberg 1963), yet there are no universally acceptable criteria for determining compound across languages. Hence the focus of research in compounding has been how to determine compoundhood in language specific perspective. It is against this background that the present study examined compounding and compound word formation processes in Ígálà. It is argued that determining or defining compoundhood in the 
language favours semantic criteria above phonological and syntactic considerations. Besides, compounding generally has been found to be a highly productive word formation process in Ígálà in terms of varieties (forms) and functions. Apart from Noun + Noun compounds, other compound types such as synthetic and verbal compounds which could equally be accounted for using semantic criteria have been attested in Ígálà. Even though endocentric nominal compounds in Ígálà generally obey Left-Hand head rule (N1 as head), synthetic compounds in Ígálà, it has been observed, exhibit the possibility for either Left-Hand head position or Right-Hand head position. However, the Right-Hand head rule found in (10a-d) may not be very productive in the language. It is adjudged as an exception rather than the rule.

Finally, in addition to the general function of lexical expansion through creation of new lexical categories or lexemes, compounding has been used copiously in naming concepts, particularly foreign institutions, ideas, items or objects, and concepts that were hitherto non-existent in Ígálà. Lexical expansion through compounding, the paper argues, is found to be more productive, more natural, and much more functionally motivating in the language compared to borrowing and or transliteration. This is because such compositions (compounding) serve to convey better a broad range of semantic notions (including foreign concepts) which are in tandem with the culturally recognizable activities and worldview of the people. As it has been argued in the preceding section (cf. section 4, last paragraph), the implication of the assertion is that, since compounding is a universal phenomenon, it could be safe to conclude that the observation may hold for all other languages of the world in which compounding is attested as a productive word formation process. 


\section{References}

Altmann, G. 1988. Hypothesis about Compounds. Glottometrika 10. Bochum: Brockmeyer.

Anagbogu, P. 1990. The Grammar of İgbò Nominalizations. Onitsha: The University Press.

1995. The Strong Boundary Condition for Compounds:

The İgbò Perspective. In E. Emenanjo \& O-M. Ndimele (eds.), Issues in African Languages and Linguistics: Essays in Honour of Kay Williamson 246-257. Aba: NINLAN Books. 2000. The Semantic Link in İgbò Nominal Compounding.

Journal of the Linguistic Association of Nigeria 5, 40-44.

2003. Prefixes of the Koring Verb. In O-M. Ndimele (ed.), Four Decades in the Study of Language and Linguistics: A Festschrift for Kay Williamson 691-699. Aba: NINLAN Books.

2011. Introduction to Morphology. In G. Omachonu (ed.), NSUK Texts in General Linguistics 99-134. Enugu-Nigeria: Rossen Production and Services Ltd.

Anagbogu, P. \& G. Omachonu. (To Appear) Headedness and Demarcation in Nominal Compounds: Evidence from Ígálà, Ìgbò, Kọ̀rìng, and Yorùbá. Journal of West African Languages 40.1 .

Armstrong, R. 1951. A Preliminary Report with Wordlist. Ibadan: University of Ibadan.

. 1965. Comparative Wordlists of Two Dialects of Yoruba

with Igala. Journal of West African Languages 2.2, 51-78.

Atadoga, F. 2011. Igala Morphology. In G. Omachonu (ed.), Igala

Language Studies 76-102. Saarbrücken: Lambert Academic

Publishing.

Awobuluyi, O. 2005. Mọ́fiìmù kan Soṣo ni \{àì\} Àbí Méjì. Journal of the Yorùbá Studies Association of Nigeria 3.1, 1-7. Aziza, R. 2007. Urhobo Morphology. In O. Yusuf (ed.), Basic 
Linguistics for Nigerian Languages Teachers 291-304. Port Harcourt: M \& J Grand Orbit Communications Ltd.

Bamgbose, A. 1965. Yoruba Orthography: A Linguistic Appraisal with Suggestions for Reforms. Ibadan: University of Ibadan. . 1967. A Short Grammar of Yorùbá. Ibadan: Heinemann Education Books.

Booij, G. 2007. The Grammar of Words. Oxford: Oxford University Press.

Bybee, J. 1985. Morphology. Amsterdam: John Benjamins.

Donalies, E. 2004. Grammatik des Deutschen im europäischen Vergleich: Kombinatorische Begriffsbildung (Teil 1: Substantivkomposition). Mannheim: Institut für deutsche Sprache.

Fabb, N. 2001. Compounding. In A. Spencer \& A. Zwicky (eds.), The Handbook of Morphology 66-83. Oxford: Blackwell Publishers Ltd.

Finney, M. 2002. Compounding and Reduplication in Krio. Journal of West African Languages 29.2, 23-34.

Gaeta, L. 2010. Synthetic Compounds: With Reference to German.

In S. Scalise \& I. Vogel (eds.), Cross-Disciplinary Issues in Compounding 219-236. Amsterdam: John Benjamins.

Giegerich, H. 2006. Attribution in English and the Distinction between Phrases and Compounds. In P. Rösel (ed.), Englisch in Zeit und Raum-English in Time and Space: Forschungsbericht für Klaus Faiss 10-27. Trier: Wissenschaftlicher Verlag Trier. Greenberg, J. 1963. Some Universals of Grammar with Particular Reference to the Order of Meaningful Elements. In J. Greenberg (ed.), Universals of Language 73-113. Cambridge, MA: MIT Press.

Guevara, E. \& S. Scalise. 2009. Searching for Universals in Compounding. In S. Scalise \& E. Bisetto (eds.), Universals of Language Today 101-128. Amsterdam: Springer.

Hebblethwaite, B. 2002. The Universality of Morpho-Syntax: Synthetic Compounding in French, English, Dutch, and Korean. Journal of Universal Language 3.2, 1-30. 
Iloene, M. 2007. İgbò Morphology. In O. Yusuf (ed.), Basic Linguistics for Nigerian Languages Teachers 181-194. Port

Harcourt: M \& J Grand Orbit Communications Ltd.

Jesperson, O. 1954. A Modern English Grammar on Historical Principles. London: Allen \& Unwin.

Jones, B. 1995. Nominal Compounds and Lexical Rules. Paper Presented at the Acquilex Workshop on Lexical Rules. Cambridge, August 9-11.

Kavka, S. 2009. Compounding and Idiomatology. In R. Lieber \&

P. Stekauer (eds.), The Oxford Handbook of Compounding

19-33. Oxford: Oxford University Press.

Kortmann, B. 2005. English Linguistics: Essentials. Berlin: Cornelsen. Levi, J. 1978. The Syntax and Semantics of Complex Nominals. New York: Academic Press.

Lieber, R. \& P. Štekauer. 2009. Introduction: Status and Definition of Compounding. In R. Lieber \& P. Štekauer (eds.), The Oxford Handbook of Compounding 3-18. Oxford: Oxford University Press.

Nwachukwu, P. 1983. Towards an İgbò Literary Standard. London: Kegan Paul.

Nwaozuzu, G. 1991. İgbò Nominal Compounds: A Semantic-

Typological Analysis. Unpublished Ph.D Dissertation. University of Nigeria.

Ogbalu, F. 1975. Ìgbò Spelling. In F. Ogbalu \& E. Emenanjo (eds.), İgbò Language and Culture 24-30. Ibadan: Oxford University Press.

Olsen, S. 2000. Compounding and Stress in English: A Closer Look at the Boundary between Morphology and Syntax. Linguistische Berichte 181, 55-69.

Oluikpe, B. \& G. Nwaozuzu. 1995. İgbò Nominal Compounds: Fact or Fiction? In E. Emenanjo \& O-M. Ndimele (eds.), Issues in African Languages and Linguistics: Essays in Honour of Kay Williamson 229-237. Aba: NINLAN Books. Omachonu, G. 2001. Igala Morphological Processes. Nsukka 
Journal of African Languages and Linguistics 2, 55-65. . 2012. Verbal Status and Serial Verb Constructions in Ígálà. Linguistisches Kolloquium. Online Publication. Afrika HU Berlin. Available at URL < http://iaaw.hu-berlin.de/afrika/ linguistik-und-sprachen/veranstaltungen/afrikalinguistischeskoll oquium/beitraege-wintersemester-2011-12>.

(To Appear) Headedness and Demarcation between

Nominal Compounds and Noun Phrases in Igala. Word Structure 5.2.

Owolabi, K. 1995. More on Yorùbá Prefixing Morphology. In K.

Owolabi (ed.), Language in Nigeria: Essays in Honour of Ayo Bamgbose 92-112. Ibadan: Group Publishers.

Oyebade, F. 2007. Yoruba Morphology. In O. Yusuf (ed.), Basic

Linguistics for Nigerian Languages Teachers 241-255. Port

Harcourt: M \& J Grand Orbit Communications Ltd.

Plag, I. 2003. Word-Formation in English. Cambridge: Cambridge University Press.

Sheard, J. 1966. The Words of English. New York: W. W. Norton. Szymanek, B. 1988. Categories and Categorization in Morphology.

Lublin: Katolicki Uniwersytet Lubelski.

Taiwo, O. 2008. Compound Verbs in Yorùbá. Studi Linguistici e Filologici Online 6, 345-370. . 2009. Headedness and the Structure of Yoruba Compound Words. Taiwan Journal of Linguistics 7.1, 27-52. 